\title{
PENGARUH PENYULUHAN KESEHATAN REPRODUKSI REMAJA TERHADAP PENGETAHUAN TENTANG PERILAKU SEKSUAL REMAJA DI SMA $X$ BANDAR LAMPUNG TAHUN 2018
}

\author{
Ameliana Puspita ${ }^{1}$ \\ ${ }^{1}$ Program Diploma IV Kebidanan, Fakultas Kedokteran Universitas Malahayati
}

\begin{abstract}
ABSTRAK
Menurut data WHO, satu dari lima perempuan di dunia telah melahirkan pada usia 18 tahun dan menurut media Indonesia menulis bahwa sebanyak 85\% remaja 15 tahun telah melakukan seks pranikah. Di kota Bandar Lampung Penyakit Menular Seksual yang dijadikan sebagai laporan utama adalah kasus HIV dan AIDS. Berdasarkan hasil pre survey yang dilakukan peneliti di SMA " $X$ " Bandar Lampung bahwa sekolah tersebut sudah lama tidak mendapatkan pendidikan kesehatan reproduksi. Tujuan penelitian ini diketahui pengaruh Penyuluhan Kesehatan Reproduksi terhadap pengetahuan tentang perilaku seksual remaja di SMA " $X$ " Bandar Lampung Tahun 2018. Jenis penelitian ini adalah kuantitatif dengan pendekatan one group prepost test design. Populasi penelitian adalah siswa-siswi kelas $X$ di SMA " $X$ " Bandar Lampung Tahun 2018 berjumlah 87 responden, sedangkan sampel penelitian berjumlah 46. Analisis dalam penelitian ini menggunakan $u j i-t$ dependen. Hasil penelitian menunjukkan rata-rata pengetahuan remaja tentang perilaku seksual sebelum pemberian Penyuluhan Kesehatan Reproduksi di SMA "X" Bandar Lampung Tahun 2018 adalah 55,41 dan sesudah adalah 76,85. Hasil p-value pengetahuan diperoleh 0,000, sehingga dapat disimpulkan ada pengaruh Penyuluhan Kesehatan Reproduksi remaja terhadap pengetahuan tentang perilaku seksual remaja di SMA " $X$ " Bandar Lampung Tahun 2018. Saran dalam penelitian ini bagi dinas kesehatan dan pendidikan untuk memberikan KIE kesehatan reproduksi secara berkala, karena pengetahuan yang baik akan mempengaruhi perilaku yang baik pula.
\end{abstract}

Kata Kunci : Penyuluhan Kesehatan Reproduksi, Pengetahuan Remaja, Perilaku Seksual

\section{PENDAHULUAN}

Kesehatan reproduksi didefinisikan sebagai keadaan sejahterah fisik, mental, dan sosial secara utuh, tidak semata-mata bebas dari penyakit atau kecacatan dalam semua hal yang berkaitan dengan sistem reproduksi, serta fungsi dan prosesnya (Kumalasari dan Andhyantoro, 2013). Remaja merupakan masa depan bagi suatu
Negara, menanamkan perhatian pada mereka pastilah memberikan manfaat besar di kemudian hari. Lebih baik lagi jika dikaitkan dengan aspek lain seperti kesehatan, gizi, dan pendidikan yang dikoordinasikan diintegrasikan dalam program-program efektif perkembangan remaja sehingga meningkatkan keberhasilan mengembangkan potensi mereka (Bartholomew et al, 2011).

Pertambahan usia anak sehingga mereka mengalami masa transisi 
menuju dewasa yang biasa disebut pubertas, bertambah pula pengaruh terhadap kesehatan mereka sendiri. Mereka harus menghadapi perubahan permasalahan kesehatan seperti meluasnya penyakit menular seksual dan HIV/AIDS. Pendidikan kesehatan berupa penyuluhan dan perilaku seksual dapat menjadi penentu penting dari kesehatan dasar baik itu selama masa remaja kemudian di masa dewasa (WHO, 2012). Setiap prilaku seksual remaja pranikah dipengaruhi oleh banyak hal, selain dari faktor pengetahuan juga dipengaruhi oleh faktor budaya, orang lain yang dianggap penting, media massa, lembaga pendidikan, lembaga agama, dan emosi dari dalam individu. Sikap seksual pranikah remaja bisa berwujud positif ataupun negatif, sikap positif kecenderungan tindakan adalah mendukung seksual pranikah sedangkan sikap negatif kecenderungan tindakan ialah menghindari seksual pranikah (Sarwono, 2011).

Menurut data WHO, satu dari lima perempuan di dunia telah melahirkan pada usia 18 tahun. Hampir semua kelahiran yang terjadi pada remaja, sekitar 95\% terjadi di Negara berpenghasilan rendah dan menengah (WHO, 2012). Dalam hal ini prilaku seksual pada remaja dapat diwujudkan dalam tingkah laku yang bermacammacam mulai dari prilaku seksual antar lain berpelukan, cium kering, cium basah, meraba bagian tubuh yang sensitif, petting, oral seks, intercourse atau bersenggama (Sarwono, 2011). Menurut Media Indonesia menulis bahwa sebanyak $85 \%$ remaja 15 tahun telah melakukan seks pranikah, sedangkan menurut harian Republika dimana hampir $50 \%$ remaja perempuan di Indonesia melakukan hubungan seks di luar nikah (Sukmadewi, 2012).
Berdasarkan survey Demografi Kesehatan Indonesia (2012) alasan utama remaja yang melakukan hubungan seksual pranikah adalah rasa ingin tahu 58\%, remaja wanita melakukan hubungan seksual dipaksa oleh pasangannya $13 \%$, sebagian besar remaja memulai pacaran diusia 15-19 tahun dan telah melakukan hubungan seksual pranikah ketika pacaran hal ini dapat dilihat remaja melakukan aktifitas berciuman bibir pada wanita $30 \%$ dan laki-laki 48\%, Meraba/merangasang pada wanita $6 \%$ dan laki-laki $30 \%$, sedangkan hubungan intim pranikah pada wanita $1 \%$ dan laki- laki $8 \%$. Masalah-masalah kesehatan reproduksi menunjukan minimnya pengetahuan akan kesehatan reproduksi. Pendidikan mengenai kesehatan reproduksi merupakan salah satu solusi pencegahan terhadap terjadinya hal tersebut. Penyuluhan oleh lembaga seperti BKKBN merupakan salah satu cara pendidikan kesehatan reproduksi. Penyuluhan lebih banyak dilaksanakan ditingkat Sekolah Menengah Atas (SMA) dari pada Sekolah Menengah Pertama (SMP) (Badan Kependudukan dan Keluarga Berencana Nasional (BKKBN, 2012).

Remaja berpendidikan lebih mampu mengelola kesehatan reproduksi dan mempertahankan kesehatan mereka sendiri sehingga pada akhirnya mereka dapat menerapkan dalam keluarganya. Hal ini melandasi pentingnya pendidikan bagi remaja terlebih lagi pendidikan kesehatan reproduksi dengan penyuluhan salah satunya menjadi aspek penting kunci dari kesehatan secara keseluruhan baik pada remaja laki - laki dan terutama remaja perempuan (WHO,2012). Risiko kesehatan reproduksi ini dipengaruhi oleh berbagai faktor yang saling berhubungan misalnya kebersihan organ-organ reproduksi, hubungan seksual pranikah, 
akses terhadap pendidikan kesehatan, kekerasan seksual, pengaruh media massa, gaya hidup yang bebas, penggunaan NAPZA, akses terhadap pelayanan kesehatan reproduksi yang terjangkau, dan kurangnya kedekatan remaja dengan kedua orangtuanya dan keluarganya (PATH, 2010).

Pentingnya pengetahuan tentang kesehatan reproduksi, remaja perlu mendapat informasi yang cukup, sehingga mengetahui hal-hal yang seharusnya dilakukan dan yang seharusnya dihindari. Dengan mengetahui tentang kesehatan reproduksi remaja secara benar, kita dapat menghindari hal-hal yang negatif yang mungkin akan dialami oleh remaja yang tidak mempunyai pengetahuan yang cukup tentang kesehatan reproduksi remaja (Wardah, 2007). Remaja juga perlu menyadari akan pentingnya pembuatan keputusan untuk menolak setiap kegiatan seksual yang rentan terjadi pada masa remaja karena setiap kegiatan seksual mempunyai risiko negatif tentang kesehatan reproduksinya. Hubungan atau kontak seksual pada remaja di bawah 17 tahun juga berisiko terhadap tumbuhnya sel kanker pada mulut rahim, penyakit menular seksual, HIV/AIDS, melakukan aborsi, dan lebih jauh dapat menyebabkan komplikasi berupa ganguan mental dan kepribadian pada remaja (Ernawati, 2007). Risiko kesehatan reproduksi remaja ini dapat ditekan dengan pengetahuan yang baik tentang Kesehatan Reproduksi Remaja (KRR). Pengetahuan tentang KRR ini dapat ditingkatkan dengan pendidikan kesehatan reproduksi yang dimulai dari usia remaja. Pendidikan kesehatan reproduksi di usia remaja bukan hanya memberikan pengetahuan tentang organ reproduksi, tetapi juga bahaya akibat pergaulan bebas, seperti penyakit menular seksual dan kehamilan yang tidak diharapkan atau kehamilan berisiko tinggi (BKKBN, 2010).

Berdasarkan Laporan perkembangan HIV-AIDS dan PIMS di Indonesia Triwulan I Tahun 2017 yang sudah di tambah dengan data kasus infeksi menular seksual (IMS) yang berasal dari unit pelayanan kesehatan, dari bulan Januari sampai dengan Maret 2017 jumlah infeksi HIV terdapat sebanyak 10.376 orang dengan persentasi infeksi tertinggi pada kelompok umur 25-49 tahun $(69,6 \%)$, diikuti kelompok umur 20-24 tahun $(17,6 \%)$, dan kelompok umur $\geq 50$ tahun $(6,7 \%)$. Sedangkan jumlah AIDS dilaporkan sebanyak 673 orang dengan persentasi tertinggi pada kelompok umur 30-39 tahun $(38,6 \%)$, diikuti kelompok umur 20-29 tahun (29,3\%), dan kelompok umur 40-49 tahun $(16,5 \%) \quad$ (Kemenkes, 2017). Di kota Bandar Lampung Penyakit Menular Seksual (PMS) yang dijadikan sebagai laporan utama adalah kasus HIV dan AIDS. Kasus HIV dan AIDS yang dilaporkan dari tahun 2002 sampai 2014 sebanyak 988 kasus (Saibumi.com Bandar Lampung, 2014). Pada tahun 2015 Kota Bandar Lampung kasus HIV/AIDS mencapai 371 kasus dengan kasus HIV sebanyak 314 kasus dan dengan kasus AIDS sebanyak 57 kasus (Profil Dinas Kesehatan Provinsi Lampung, 2016).

Peneliti akan melakukan penelitian di SMA " $X$ " Bandar Lampung karena letak geografis sekolah tersebut berada di pusat kota yang diketahui tingkat perilaku seksual remaja lebih tinggi dari pada sekolah yang berlokasi di desa. dan di SMA tersebut sudah lama tidak mendapatkan pendidikan kesehatan reproduksi. Dari hasil pre survey yang dilakukan peneliti di SMA " $X$ " Bandar Lampung, hasil wawancara 10 siswa hanya 3 orang yang tahu Bahaya perilaku seksual 
remaja. Berdasarkan latar belakang diatas dan pre survey yang dilakukan peneliti di SMA " $X$ " Bandar Lampung salah satu guru mengatakan bahwa untuk sampai sekarang belum ada angka kejadian PMS dan HIV/AIDS di SMA tersebut. Dengan demikian peneliti tertarik melakukan penelitian tentang Pengaruh Penyuluhan Kesehatan Reproduksi Remaja Terhadap Pengetahuan Tentang Perilaku Seksual Remaja di SMA " $X$ " Bandar Lampung Tahun 2018.

\section{METODOLOGI PENELITIAN}

Penelitian ini merupakan jenis penelitian kuantitatif yaitu penelitian yang mecoba menggali bagaimana dan mengapa fenomena kesehatan itu terjadi. Penelitian dilakukan pada bulan Maret - Juli 2018. Penelitian dilakukan di SMA " $X$ " Bandar Lampung. Rancangan penelitian yang digunakan dalam penelitian ini adalah pra eksperimen dengan pendekatan one group pre-post test design. Desain pra eksperimen dalam penelitian ini digunakan untuk mengetahui pengaruh penyuluhan kesehatan reproduksi remaja terhadap pengetahuan tentang perilaku seksual remaja di SMA " $X$ " Bandar Lampung Tahun 2018. Populasi penelitian adalah semua siswa kelas $X$ di SMA " $X "$ Bandar Lampung Tahun 2018 yang terdiri dari 3 kelas dengan jumlah siswa/siswi sejumlah 87 siswa, sampel 46 responden. Teknik yang digunakan adalah tehnik Simple

Random Sampling r yaitu
pengambilan sampel secara acak
sederhana yaitu dengan mengundi
(lottery
(Notoatmodjo,2010).

Variabel Independen dalam penelitian ini adalah penyuluhan. Variabel dependen dalam penelitian ini adalah pengetahuan tentang HIV \& AIDS. Alat pengumpulan data dalam penelitian ini menggunakan beberapa alat pengumpulan data. Data pengetahuan responden diambil melalui nilai pre test dan post test dengan menggunakan soal pre test dan post test. Kuesioner yang digunakan bersumber dari panduan kampanye ABAT (terstandarisasi), sehingga peneliti tidak melakukan uji validitas dan reliabilitas (Kemenkes RI, 2012) Selanjutnya nilai tersebut dientry dalam lembar observasi. Analisa univariat dilakukan untuk mendapatkan gambaran statistik deskriptif dari masing-masing variabel, baik variabel independen maupun dependen. Data yang terkumpul dalam penelitian ini akan diolah dengan menggunakan komputer. Untuk data numerik digunakan nilai mean (rata-rata), median, standar deviasi dan inter kuartil range, minimal dan maksimal (Hastono, 2007). Untuk mengetahui ada tidaknya pengaruh Media KIE "Aku Bangga Aku Tahu" terhadap pengetahuan remaja tentang HIV \& AIDS di SMA "P" Bandar Lampung Tahun 2017. Uji statistik yang digunakan adalah uji tDependent dengan bantuan komputer. 


\section{HASIL PENELITIAN}

1. Karakteristik Responden

Tabel 1. Karakteristik Responden di SMA "X" Bandar Lampung Tahun 2018

\begin{tabular}{|c|c|c|c|c|c|}
\hline \multirow[b]{3}{*}{ Umur } & \multicolumn{3}{|c|}{ Jenis Kelamin } & & \multirow[b]{3}{*}{ Total } \\
\hline & Laki-I & & Perempuan & & \\
\hline & $\mathrm{n}$ & $\%$ & $\mathrm{n}$ & $\%$ & \\
\hline 14 Tahun & 6 & 46.2 & 7 & 53.8 & 13 \\
\hline 15 Tahun & 11 & 42.3 & 15 & 57.6 & 26 \\
\hline 16 Tahun & 4 & 57.1 & 3 & 42.9 & 7 \\
\hline Total & 21 & 45.6 & 25 & 54.3 & 46 \\
\hline
\end{tabular}

Berdasarkan tabel 1. diketahui bahwa sebagian besar responden berjenis kelamin Perempuan yaitu sebanyak 25 responden (54.3\%), dengan usia terbanyak 15 tahun yaitu 26 orang.

2. Analisis Univariat

a. Pengetahuan remaja tentang perilaku seksual sebelum dan sesudah pemberian penyuluhan kesehatan reproduksi

Tabel. 2 Pengetahuan Remaja Tentang Perilaku Seksual Sebelum Dan Sesudah Di Berikan Penyuluhan Kesehatan Reproduksi Remaja Di Sma "X" Bandar Lampung Tahun 2018

\begin{tabular}{ccccc}
\hline Variabel & Mean & SD & Min- mak & $\mathbf{9 5} \% \mathbf{C l}$ \\
\hline $\begin{array}{c}\text { Pengetahuan } \\
\text { Sebelum }\end{array}$ & 55,41 & 11,28 & $40-73$ & 52,06 \\
$\begin{array}{c}\text { Pengetahuan } \\
\text { Sesudah }\end{array}$ & 76,85 & 6,92 & $60-86$ & - \\
\hline
\end{tabular}

\begin{abstract}
Berdasarkan tabel 2. hasil analisis didapatkan rata- rata pengetahuan remaja tentang perilaku seksual sebelum pemberian penyuluhan kesehatan reproduksi di SMA " $X$ " Bandar Lampung Tahun 2018 adalah 55,41 (95 \% CI: 52,06 - 58,76), standar deviasi sebesar 11,28, nilai minimal
\end{abstract}

\section{Analisis Bivariat}

Dikarenakan hasil uji normalitas menunjukkan nilai sig pada nilai pengetahuan pretest 0,074 dan posttest 0,010 dapat disimpulkan bahwa
40 dan maksimal 73. Sesudah pemberian penyuluhan kesehatan reproduksi remaja di SMA " $X$ " Bandar Lampung Tahun 2018 adalah 76.85 (95 \% CI: 74,79 - 78,90), standar deviasi sebesar 6,92, nilai minimal 60 dan maksimal 86.

distribusi data tidak normal, sehingga analisis data menggunakan uji Wilcoxon. Berdasarkan hasil uji hipotesis diterangkan dalam tabel berikut: 
Tabel 3. Pengaruh Penyuluhan Kesehatan Reproduksi Remaja terhadap Pengetahuan Tentang Perilaku Seksual Remaja di SMA "X" Bandar Lampung Tahun 2018

\begin{tabular}{lllll}
\hline Pengetahuan & Mean & SD & Mean Rank & P Value \\
\hline Sebelum & 55,41 & 11,28 & 23,0 & 0,000 \\
Sesudah & 76,85 & 6,92 & & \\
\hline
\end{tabular}

Berdasarkan tabel 3. diketahui bahwa nilai rata- rata pengetahuan remaja tentang Perilaku Seksual sebelum pemberian penyuluhan kesehatan reproduksi remaja di SMA " $X$ " Bandar Lampung Tahun 2018 adalah 55,41. Sedangkan rata-rata pengetahuan remaja tentang Perilaku Seksual sesudah pe penyuluhan

\section{PEMBAHASAN}

1. Univariat

a. Pengetahuan Remaja tentang perilaku seksual remaja sebelum Pemberian penyuluhan kesehatan reproduksi

Hasil penelitian menunjukkan rata-rata pengetahuan remaja tentang perilaku seksual remaja sebelum pemberian penyuluhan kesehatan reproduksi di SMA " $X$ " Bandar Lampung Tahun 2018 adalah 54,41 (95 \% CI: 52,06 - 58,76), standar deviasi sebesar 11,28, nilai minimal 40 dan maksimal 73. Pengetahuan adalah hasil dari tahu, dan ini terjadi setelah seseorang melakukan pengindraan terhadap suatu objek tertentu. Pengindraan terjadi melalui panca indra mabusia, yakni indra penglihatan, pendengaran, penciuman, rasa, dan perabaan. (Notoatmodjo, 2010).

Menurut Erfandi (2009), faktor-
faktor yang mempengaruhi
pengetahuan adalah pendidikan, media
massa atau informasi, sosial budaya dan
ekonomi, lingkungan, pengalaman dan
usia. Pendidikan mempengaruhi proses
belajar, makin tinggi pendidikan
seseorang makin mudah seseorang

kesehatan reproduksi remaja di SMA " $X$ " Bandar Lampung Tahun 2018 adalah 76.85 dengan mean rank 23,0 Hasil $p$ value diperoleh 0,000 maka dapat disimpulkan ada pengaruh penyuluhan kesehatan reproduksi remaja terhadap pengetahuan tentang perilakuseksual remaja di SMA " $X$ " Bandar Lampung Tahun 2018. 
berkembang pula daya tangkap dan pola pikirnya, sehingga pengetahuan yang diperoleh semakin membaik.

Berdasarkan penelitian diatas sebagian besar responden mempunyai pengetahuan yang kurang skor $<55$ mengenai perilaku seksual remaja. Pengetahuan tentang perilaku seksual remaja penting diketahui oleh remaja karena kelompok umur remaja termasuk tinggi jumlahnya mengidap penyakit PMS dan HIV/AIDS. Sehingga remaja sangat penting mengetahui tentang pengetahuan Perilaku Seksual.

b. Pengetahuan Remaja tentang perilaku seksual remaja sesudah Pemberian penyuluhan kesehatan reproduksi remaja

Hasil penelitian menunjukkan rata-rata pengetahuan remaja tentang perilaku seksual remaja sesudah pemberian penyuluhan kesehatan reproduksi remaja di SMA " $X$ " Bandar Lampung Tahun 2018 adalah 76.85 (95 \% CI: 74,79 - 78,90), standar deviasi sebesar 6,92 nilai minimal 60 dan maksimal 86. Hasil penelitian ini sesuai dengan pendapat Notoatmodjo yang menyatakan bahwa perilaku baru terutama pada remaja dimulai pada domain kognitif dalam arti subjek tahu terlebih dahulu terhadap stimulus yang berupa materi objek diluarnya menimbulkan respon batin dalam bentuk sikap. Akhirnya rangsangan yakni objek yang telah diketahui dan disadari sepenuhnya tersebut akan menimbulkan respon lebih jauh lagi yaitu berupa tindakan terhadap stimulus atau objek. Pengetahuan merupakan langkah awal dari seseorang untuk menentukan sikap dan perilakunya. Jadi tingkat pengetahuan akan sangat berpengaruh terhadap penerimaan suatu program (Notoatmodjo, 2010).

\section{Bivariat}

Hasil penelitian menunjukkan ada pengaruh penyuluhan kesehatan reproduksi remaja terhadap pengetahuan tentang perilaku remaja di SMA "X" Bandar Lampung Tahun 2018 ( $p$ value 0,000). Pengetahuan merupakan hasil tahu yang terjadi setelah orang melakukan penginderaan terhadap suatu objek tertentu melalui panca indera manusia, yaitu indera penglihatan, pendengaran, penciuman, rasa dan raba dimana sebagian besar diperoleh melalui mata dan telinga Pengetahuan didapat secara formal dan informal. Pengetahuan secara formal didapat dari sekolah dan pengetahuan secara informal misalnya didapat dari penyuluhan kesehatan, informasi dari teman, orang tua, maupun dari berbagai media informasi. Disekolah dalam proses pembelajaran terjadi proses penyampaian materi pendidikan dari pendidik kepada sasaran (anak didik) untuk mencapai perubahan tingkah laku (Notoatmodjo, 2010).

Menurut Notoatdmojo (2010), tingkat pengetahuan seseorang dipengaruhi oleh faktor pendidikan yaitu bimbingan yang diberikan seorang terhadap perkembangan orang lain sehingga seseorang tersebut menjadi tahu. Hasil penelitian diatas menunjukkan bahwa telah terjadi perubahan pengetahuan seperti yang diharapkan dari penyuluhan kesehatan. Diharapkan pengetahuan ini dapat merubah perilaku seksual remaja SMA terhadap perilaku seksual yang bebas. Peningkatan pengetahuan ini karena adanya pemberian informasi, dimana didalamnya terdapat proses belajar. Proses belajar menurut Notoatmodjo (2010), dapat diartikan sebagai proses untuk menambah pengetahuan, pemahaman, dan keterampilan yang dapat diperoleh 
melalui pengalaman atau melakukan studi (proses belajar mengajar). Dengan belajar individu diharapkan mampu menggali apa yang terpendam dalam dirinya dengan mendorong untuk berpikir dan mengembangkan kepribadiannya dengan membebaskan diri dari ketidaktahuannya. Hal ini sejalan dengan tujuan dari dilakukannya penyuluhan kesehatan yang dikemukakan oleh Notoatmodjo (2010), yakni peningkatan pengetahuan masyarakat di bidang kesehatan, tercapainya perubahan perilaku, individu, keluarga, dan masyarakat sebagai sasaran utama penyuluhan kesehatan dalam membina perilaku sehat dan lingkungan sehat serta berperan aktif dalam upaya meningkatkan derajat kesehatan yang optimal sesuai dengan konsep sehat sehingga dapat menurunkan angka kesakitan dan kematian. Hal ini sejalan dengan penelitian terkait yaitu penelitian Eti Dwi Setyaningrum (2014) Penelitian tentang "pengaruh penyuluhan tentang seks pranikah terhadap pengetahuan dan sikap remaja dalam pencegahan seks pranikah di SMK N 1 Sewon Bantul Yogyakarta Tahun 2014". Di dapatkan hasil penelitian bahwa terdapat peningkatan pengetahuan tentang seks pranikah.. Hal ini juga Sejalan dengan penelitian Wustha Bachruddin, dkk (2017) penelitian tentang "pengaruh penyuluhan tentang bahaya seks bebas terhadap pengetahuan remaja tentang seks bebas di SMA N BINSUS 9 Manado". Hasil penelitian adalah terdapat pengaruh penyuluhan tentang bahaya seks bebas terhadap pengetahuan remaja tentang seks bebas.

Setiap prilaku seksual remaja pranikah dipengaruhi oleh banyak hal, selain dari faktor pengetahuan juga dipengaruhi oleh faktor budaya, orang lain yang dianggap penting, media massa, lembaga pendidikan, lembaga agama, dan emosi dari dalam individu. Sikap seksual pranikah remaja bisa berwujud positif ataupun negatif, sikap positif kecenderungan tindakan adalah mendukung seksual pranikah sedangkan sikap negatif kecenderungan tindakan ialah menghindari seksual pranikah (Sarwono, 2011).

Menurut peneliti pendidikan kesehatan tentang perilaku seksual cukup efektif dan efisien serta memberikan pengaruh untuk meningkatkan pengetahuan remaja SMA namun ditemukan terdapat responden yang mengalami peningkatan pengetahuan tidak signifikan, Peneliti berasumsi bahwa hal ini dapat disebabkan oleh beberapa faktor, yaitu faktor peneliti, faktor responden, dan faktor sarana dan prasarana. Ditinjau dari faktor peneliti yaitu peneliti belum mampu mengontrol suasana dan keadaan proses penelitian secara maksimal, sehingga terdapat beberapa responden yang kurang memerhatikan informasi yang disampaikan oleh peneliti. Pada faktor responden terdapat beberapa alasan yang mungkin menyebabkan penurunan pengetahuan tersebut, seperti kemampuan penyerapan informasi yang berbedabeda pada setiap orang. Penerimaan informasi baru yang belum pernah didengar sebelumnya dapat menyebabkan responden mengalami kesulitan dalam memahami informasi yang diberikan.

Kesalahan persepsi responden
juga dapat menjadi salah satu
penyebab tidak meningkatnya
pengetahua responden atau
penurunan pengetahuan responden. Jika
seseorang salah mengartikan informasi
yang mereka terima, hal itu dapat
menimbulkan persepsi yang salah
tentang informasi tersebut, sehingga
dalam pengisian kuesioner, reponden


menjawab pernyataan berdasarkan pemahaman yang mereka pahami. Intensitas perhatian responden atau kemauan responden untuk mendengarkan informasi yang disampaikan oleh peneliti juga menjadi salah satu faktor yang berperan penting dalam perubahan pengetahuan responden. Hal ini sejalan dengan teori yang menyatakan bahwa beberapa faktor dapat menjelaskan penurunan skor pengetahuan dan salah satunya adalah faktor internal yang terdiri atas faktor biologis (jasmaniah) dan faktor psikologis (rohaniah). Faktor internal merupakan faktor yang berasal dari dalam individu itu sendiri, sedangkan faktor biologis meliputi semua yang berkaitan dengan kondisi fisik dan jasmani individu yang bersangkutan. Faktor psikologis merupakan hal yang berpengaruh terhadap keberhasilan pemahaman seseorang meliputi segala yang berkaitan dengan mental dan meliputi 3 hal, yaitu intelegensi, kemauan, dan daya ingat.

\section{KESIMPULAN}

1. Rata-rata pengetahuan remaja tentang Perilaku Seksual sebelum pemberian Penyuluhan Kesehtan Reproduksi di SMA " $X$ " Bandar Lampung Tahun 2018 adalah 55,41.

2. Rata-rata pengetahuan remaja tentang Perilaku Seksual sesudah pemberian Penyuluhan Kesehtan Reproduksi di SMA " $X$ " Bandar Lampung Tahun 2018 adalah 76,85.

3. Hasil $p$ value diperoleh 0,000 maka dapat disimpulkan ada pengaruh Penyuluhan Kesehatan Reproduksi terhadap pengetahuan remaja tentang perilaku seksual remaja di SMA " $X$ " Bandar Lampung Tahun 2018

\section{DAFTAR PUSTAKA}

Arikunto, Suharsimi (2014). Prosedur Penelitian Suatu Pendekatan Praktik. Jakarta : Rineka Cipta

Bachruddin, Wustha (2017). Pengaruh Penyuluhan tentang Bahaya Seks Bebas Terhadap Pengetahuan Remaja tentang Seks Bebas di SMA Negeri Binsus 9 Manado. Laporan Penelitian Skripsi Program Studi Ilmu Keperawatan Universitas Sam Ratulangi. Manado

Bartholomew, L.k. dkk (2011). Planning Health Promotion Program, an Intervention Mapping Approach 3th. Ed San Fransisco : JosseyBass

Budiman dan Agus Riyanto (2014). Kapita Selekta Kuesioner, Pengetahuan dan Sikap dalam Penelitian Kesehatan. Jakarta : Salemba Medika

Departemen Kesehatan RI (2017). Profil Kesehatan Indonesia 2016.

C: \Users\User\Downloads \Docume nts \ata dan Informasi Kesehatan Profil Kesehatan Indonesia 2016 - smaller size web.pdf. Diakses pada tanggal 24 Febuari 2018

\section{Dinas Kesehatan Provinsi Lampung (2015). Profil Kesehatan Lampung 2015. \\ C: \Users\User\Downloads\Docume nts $\backslash 0$ 8_Lampung_2015.pdf. Diakses pada tanggal 24 Febuari 2018.}

Irianto, Koes (2015). Kesehatan Reproduksi, Reproductive health, Teori \& Pratikum. Bandung : ALFABETA, CV

Kementrian Kesehatan RI (2017). Laporan Perkembangan HIV-AIDS 
dan Penyakit Infeksi Menular Seksual (PIMS) Triwulan I Tahun 2017.

C: \Users\User\Downloads \Docume nts \Lapo

ran_HIV_AIDS_TW_1_2017_rev.pd

f. Diakses pada tanggal 24 Febuari 2018

Kumalasari, Intan. Iwan Andhyantoro (2013). Kesehatan Reproduksi Untuk Mahasiswa Kebidanan dan Keperawatan. Jakarta : Salemba Medika

Kusmiran, Eny (2013). Kesehatan Reproduksi Remaja dan Wanita. Jakarta : Salemba Medika

Lubis, Namora Lumongga (2013). Psikologi Kespro, Wanita \& Perkembangan Reproduksi Ditinjau dari Aspek Fisik dan Psikologi. Jakarta : Kencana Prenada Media Group

Lupiyoadi, Rambat \& Ridho Bramulya Ikhlas (2015). Pratikum Metode Riset Bisnis. Jakarta : Salemba Empat

Notoatmodjo, Soekidjo (2012). Promosi Kesehatan dan Perilaku Kesehatan Edis Revisi 2012. Jakarta : PT. Rineka Cipta

Notoatmodjo, Soekidjo (2012). Metode Penelitian. Jakarta : PT. Rineka Cipta

Prawirohardjo, Sarwono (2014). Ilmu Kebidanan. Jakarta : PT. Bina Pustaka

Reis, Marta (2011). The Effects Of Sex Education In Promoting Sexual And Reproduktive Health In Portuguese University Students. Portugal : Faculty Of Human Kinetics.

Sarwono, Sarlito W. (2010). Psikologi Remaja. Jakarta : Rajawali Pers
Setyaningrum, Erna \& Zulfa Binti Aziz (2014). Pelayanan Keluarga Berencana \& Kesehatan Reproduksi. Jakarta Timur : CV. Trans Info Media

Setyaningrum, Eti Dwi (2014). Pengaruh Penyuluhan Tentang Seks Pranikah Terhadap Pengetahuan dan Sikap Remaja Dalam Pencegahan Seks Pranikah di SMKN 1 Sewo Bantul Yogyakarta Tahun 2014. Naskah Publikasi Program Studi Kebidanan di Sekolah Tinggi Ilmu Kesehatan. Yogyakarta.

Sujarweni, V. Wiratna (2014). Metoologi Penelitian Lengkap, Praktis, dan Mudah Dipahami. Yogyakarta : Pustaka Baru Press

Survey Demografi dan Kesehatan Indonesia (2012). Kesehatan Reproduksi Remaja.

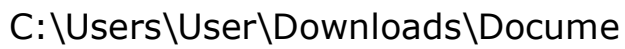
nts $\backslash S \quad$ DKI-2012-RemajaIndonesia.pdf. Diakses tanggal 14 Maret 2018

Susanti, Ely (2013) Pengaruh Promosi Kesehatan Reproduksi Remaja Terhadap Sex Bebas Pada Siswa SMK MUHAMADIYAH 2 BANDAR LAMPUNG Tahun Pelajaran 2012\2013. Skripsi Program Studi Kebidanan Malahayati Bandar Lampung tahun 2013.

Susanto, R Clevere dan GA Made Ari M (2013). Penyaki Kulit Dan Kelamin. Yogyakarta: Nuha Medika

WHO (2012). Social Determinants Of Sexual and Reproductive Health. http://www.

On.org.popin/unfpa/taskforce/guid e/iatr eph.gdl.html. Diakses tanggal 14 Maret 2018

Widyastuti, Yani, dkk (2009). Kesehatan Reproduksi. Yogyakarta : Fitramaya 